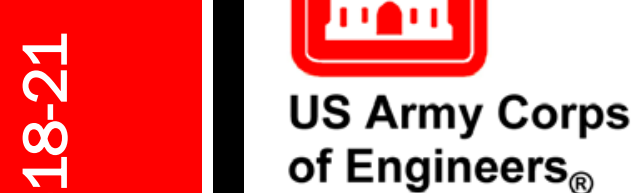

\title{
HERDC
}

Engineer Research and

Development Center

Installation Technology Transition Program

\section{Evaluation of Insulated Pavements to Prevent Frost Damage}

Marissa J. Torres, Alexander R. Stott, and

December 2018

Marina I. Reilly-Collette

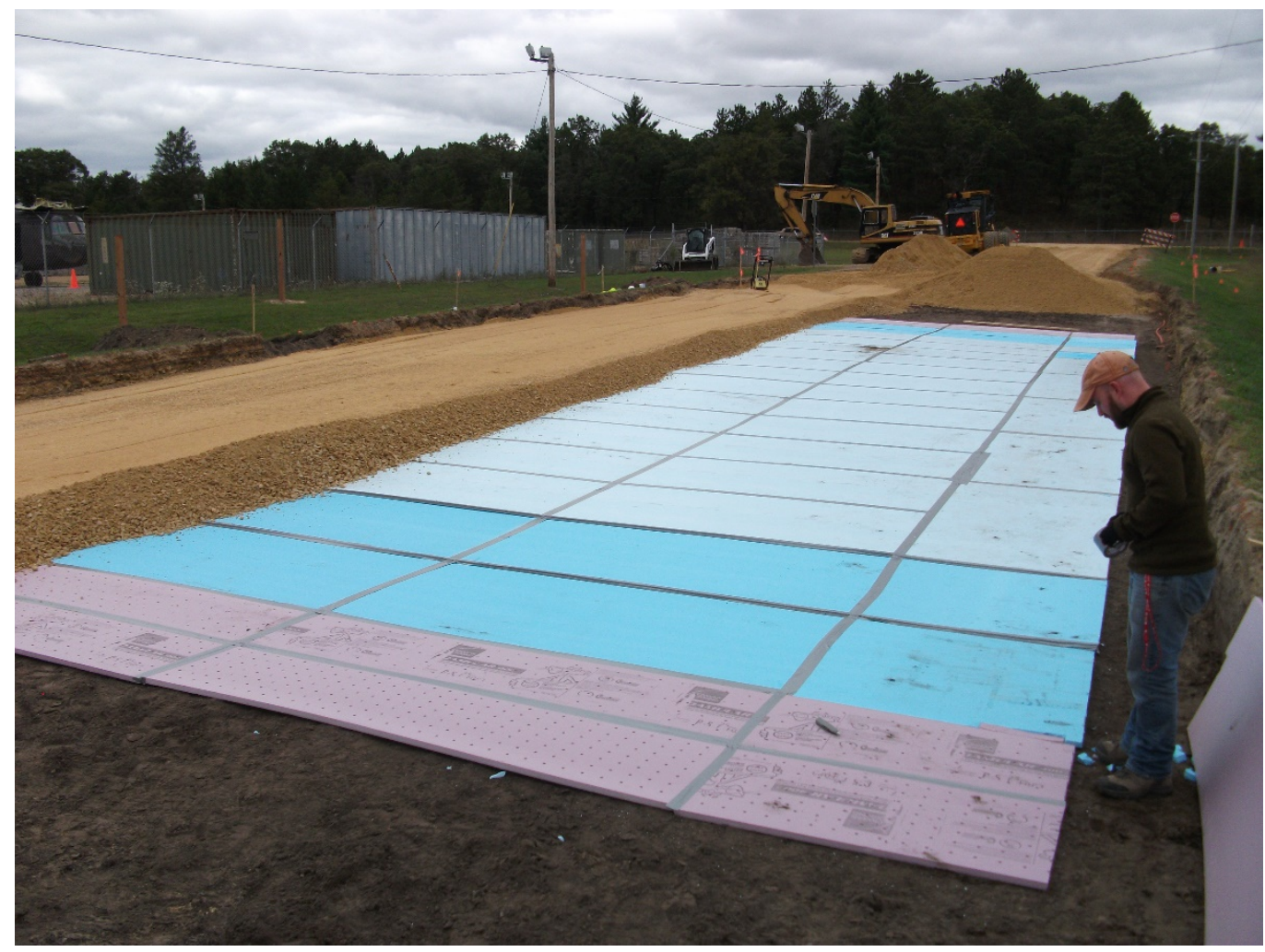


The U.S. Army Engineer Research and Development Center (ERDC) solves the nation's toughest engineering and environmental challenges. ERDC develops innovative solutions in civil and military engineering, geospatial sciences, water resources, and environmental sciences for the Army, the Department of Defense, civilian agencies, and our nation's public good. Find out more at www.erdc.usace.army.mil.

To search for other technical reports published by ERDC, visit the ERDC online library at http://acwc.sdp.sirsi.net/client/default. 


\section{Evaluation of Insulated Pavements to Prevent Frost Damage}

Marissa J. Torres, Alexander R. Stott, and Marina I. Reilly-Collette

Cold Regions Research and Engineering Laboratory

U.S. Army Engineer Research and Development Center

72 Lyme Rd

Hanover, NH 03755

Final report

Approved for public release; distribution is unlimited.

Prepared for Office of the Assistant Chief of Staff

for Installation Management

600 Pentagon

Washington, DC 20310

Under Project \# 463294, “Evaluation of Insulated Pavements to Prevent Frost Damage" 


\section{Abstract}

Frost heaving is a constant burden on any facility in cold regions, causing accelerated deterioration of roadways and annual maintenance, leading to costly repairs. Insulated pavements have been demonstrated as cost effective in several civilian locations, and have shown exceptional resistance to compression and water absorption. The objective of this study was to evaluate the effectiveness of insulated pavement in eliminating the impact of frost action on roadways for the purpose of reducing annual roadway maintenance and redefining the standards governing its application.

An insulating layer of extruded polystyrene (XPS) was installed in a section of road at Fort McCoy, WI. The monthly temperature and moisture content gradients were compared between the insulated and non-insulated pavements. The change in elastic moduli was also compared between the two pavement sections over the $2017-2018$ winter freeze and spring thaw cycle. The insulating layer was shown to be effective in preventing frost from penetrating the subgrade. Temperatures remained above freezing in the subgrade throughout the winter. The vertical moisture gradient demonstrated minimal signs of frost penetration. The presence of a high water table beneath the test pavement sections are believed to have affected the strength of the subgrade, especially through the post spring thaw recovery period.

DISCLAIMER: The contents of this report are not to be used for advertising, publication, or promotional purposes. Citation of trade names does not constitute an official endorsement or approval of the use of such commercial products. All product names and trademarks cited are the property of their respective owners. The findings of this report are not to be construed as an official Department of the Army position unless so designated by other authorized documents. 


\section{Contents}

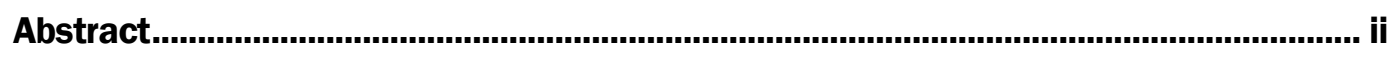

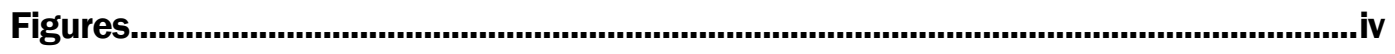

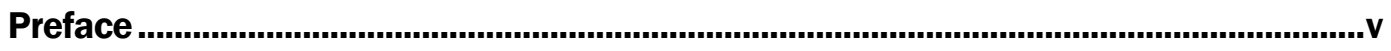

Unit Conversion Factors................................................................................................vi

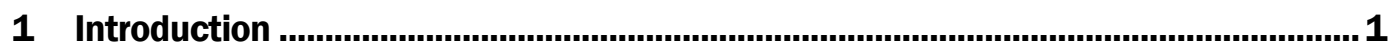

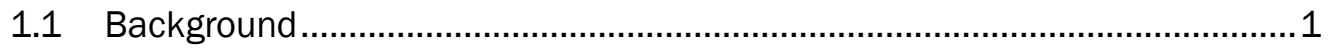

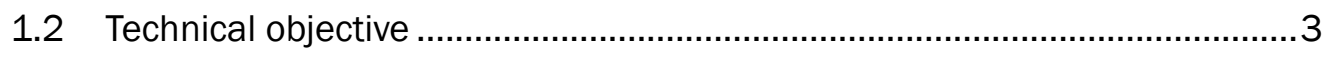

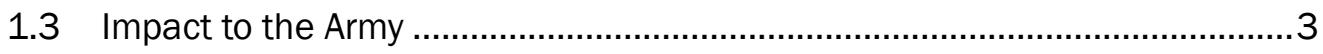

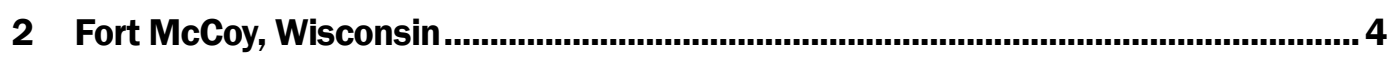

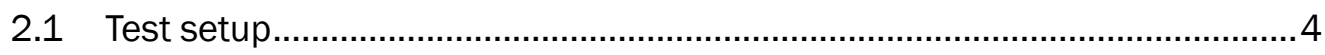

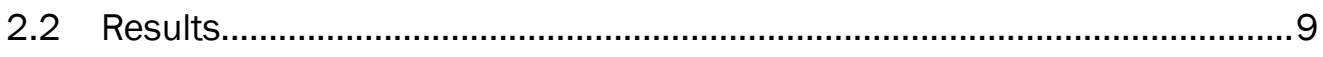

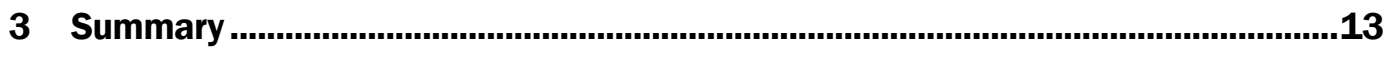

References..........................................................................................................15

Report Documentation Page 


\section{Figures}

Figure 1. (a) Aerial location of test area at Fort McCoy, WI, and (b) diagram of insulation, transition, and control section component composition and dimensions, and top-view of sensor placement.

Figure 2. Vertical depth profile of the insulated (left) and non-insulated (right) pavement sections at the test site in Fort McCoy, WI. Sensor depths measured from bottom of asphalt layer; approximate depth of standing water is noted in each diagram.

Figure 3. Approximate locations of the falling weight deflectometer (FWD) tests performed on East South Street at Fort McCoy.

Figure 4. (a) Temperature gradient in ${ }^{\circ} \mathrm{C}$ and (b) percent water content (i.e., moisture) of insulated (left) and non-insulated (right) pavement sections for October 2017 through June 2018; depth is measured from the bottom of the asphalt layer.

Figure 5. Back calculated elastic moduli in ksi of the subgrade layer (frost susceptible soil) in the insulated and non-insulated pavement section in the western and eastern lanes of East South Street. 


\section{Preface}

This study was conducted for the Office of the Assistant Chief of Staff for Installation Management under the U.S. Army Installation Technology Transition Program (ITTP), Project Number 463294, "Evaluation of Insulated Pavements to Prevent Frost Damage.” The technical monitor was Ms. Marina Reilly-Collette, U.S. Army Engineer Research and Development Center, Cold Regions Research and Engineering Laboratory (ERDCCRREL).

The work was performed by the Engineering Resources Branch (CEERDRRE) of the Research and Engineering Division (CEERD-RR), ERDCCRREL. At the time of publication, Mr. Jared Oren was Chief, CEERDRRE; Mr. J. D. Horne was Chief, CEERD-RR; and Dr. Mark L. Moran, CEERD-RZT was the Technical Director. The Deputy Director of ERDCCRREL was Dr. David B. Ringelberg and the Director was Dr. Joseph L. Corriveau.

COL Ivan P. Beckman was the Commander of ERDC, and Dr. David W. Pittman was the Director. 


\section{Unit Conversion Factors}

\begin{tabular}{|l|c|l|}
\hline Multiply & By & To Obtain \\
\hline cubic feet & 0.02831685 & cubic meters \\
\hline cubic inches & $1.6387064 \mathrm{E}-05$ & cubic meters \\
\hline degrees Fahrenheit & $(\mathrm{F}-32) / 1.8$ & degrees Celsius \\
\hline feet & 0.3048 & meters \\
\hline inches & 0.0254 & meters \\
\hline inch-pounds (force) & 0.1129848 & newton meters \\
\hline square feet & 0.09290304 & square meters \\
\hline square inches & $6.4516 \mathrm{E}-04$ & square meters \\
\hline
\end{tabular}




\section{Introduction}

Each year, roadways in cold climates are subjected to periods of frost heaving and thaw weakening which leaves roads rutted and cracked during spring trafficking. Frost heaving occurs when frost susceptible soil, subzero temperatures, and a water source are present simultaneously, and by removing any one of these elements, frost heaving can be prevented. One cost-effective approach to prevent subzero temperatures from penetrating into the frost susceptible soil (subgrade) is to place a layer of insulation between the base course and subgrade. Presently, general Army construction standards do not incorporate the use of insulated pavements at Army installations in cold regions. Therefore, a section of insulated pavement was installed on a heavily trafficked military base to acquire a supporting dataset to aid in the development of new standards for its use.

This report details the installation of extruded polystyrene (XPS) into a section of road at the Fort McCoy, WI, military base. Records of subsurface soil temperature and moisture content were collected above and below the insulating layer, and compared with a section of conventional pavement to be used as a control. Further, a series of nondestructive tests were conducted to assess the structural properties of the pavement.

The report will proceed as follows: Section 1.1 provides a brief history of insulated pavement projects across the country. Section 2 describes the roadway and climatological conditions at Fort McCoy, as well as the test set up (Section 2.1) and results (Section 2.2) for this experiment. This report concludes with a summary in Section 3 .

\subsection{Background}

Insulated pavements have been demonstrated as cost effective in a number of locations including Maine, Michigan, Wyoming, Iowa, Ontario, Saskatchewan, and Manitoba (Kestler and Berg 1995; Dow 2008). As early as the 1960s, XPS was incorporated into experimental test sections of highways, and showed exceptional resistance to compression and water absorption (Dow 2008). Alternate foam products, such as expanded polystyrene (EPS; i.e., bead-board), foamed-in-place (FIP) polyurethane, urea-formaldehyde, and sulfur foam, were later tested and found to absorb too much moisture (Vinson et al. 1996). 
The primary concern with incorporating insulation panels in pavement is the undesired effect of differential icing and heaving. Differential icing is the phenomenon where a section of pavement cools and subsequently ices differently than an adjacent section. The presence of an insulating layer induces this cooling effect at the pavement surface, leading to more slippery conditions when compared to the unfrozen surface of the adjacent conventional pavement (Côté and Konrad 2005). The development of differential icing minimized the use of insulated pavements by government agencies and state departments for a number of years. However, subsequent research led to updated designs that minimize or eliminate differential icing, and have now been well demonstrated on civilian installations (Côté and Konrad 2005). Successful installations in Alaska (Berg 1973), New Hampshire (Eaton and Dukeshire 1976), and Maine (Kestler and Berg 1995) have produced promising results and improved the methodology and understanding of insulated pavements overall.

Further, thermal design thicknesses for pavements is outlined by the Army and Air Force in TM 5-825-2 and AFJMAN 32-1014 (1997), respectively, using a design air-freezing index. Design charts estimate that approximately $1 / 2$ inch of insulation per 500 degree Fahrenheit $\left({ }^{\circ} \mathrm{F}\right)$ freezing days is required to prevent frost from penetrating into the subgrade. Recommended insulation depths vary from 18 inches to 30 inches to prevent surface icing.

In pavement design, it is important to assess the load bearing capacity and structural contribution of each layer in the system (e.g., pavement, base course, and subgrade). The stiffness and strength of the subgrade is most important in seasonal frost locations since it is most susceptible to frost heaving. In the field, the physical properties of the pavement, base course, and subgrade layers can be tested using nondestructive testing techniques. Falling Weight Deflectometer (FWD) testing is a common nondestructive technique that applies several dynamic loads of increasing force to the pavement surface, and measures the corresponding deflection of the pavement in several different locations. Supplemental software combines known variables (e.g., loading force, pavement surface temperature, layer thickness for both pavement and base course, and layer material type, etc.) to back calculate the elastic moduli of each layer. The elastic modulus of a material provides a measure of its resistance to deformation (i.e., stiffness) and its bearing capacity (i.e., strength). These characteristics will change with temperature as the material cools in the winter and warms in the 
spring and summer months. Therefore, FWD testing should be conducted periodically throughout the winter freeze cycle, and more frequently during the spring thaw cycle.

\subsection{Technical objective}

The objective of this study is to evaluate the effectiveness of insulated pavement in eliminating the impact of frost action on roadways for the purpose of reducing annual roadway maintenance and redefining the standards governing its application.

\subsection{Impact to the Army}

Frost heaving is a constant burden on any facility in cold regions, causing accelerated deterioration of roadways and annual maintenance, which ultimately leads to costly repair and reconstruction efforts. Insulated roads are significantly more resilient to the damaging effects of the frost-thaw cycle than conventional pavement. The utilization of insulated pavements can extend pavement life and shorten load restriction times. 


\section{Fort McCoy, Wisconsin}

Fort McCoy is a 60,000-acre U.S. Army installation located in Wisconsin, including 46,000 acres of live-fire and maneuver areas. The base hosts more than 100,000 military personnel each the year for field and classroom training for both reserve and active forces from all service branches. Fort McCoy has been the training site of choice since the 1980 s, and remains a vital resource to the military command and community.

Over the years, a number of asphalt roadways at Fort McCoy have experienced shortened lifespans and costly annual repairs due to seasonal frost heaving, thaw settlement, and associated surface distresses, such as alligator/fatigue cracking, frost heave damage, and rutting. Capitalizing on previous CRREL pavement prototypes and modified construction procedures, the CRREL team designed and installed a prototype pavement section on one of Fort McCoy's roads. The installation uses low-cost construction materials to provide insulation below the base course, preventing sub-freezing temperatures from reaching the subgrade and thereby preventing winter heaving. This prototype section, if successful and extended to other areas of ailing pavements, is estimated to help Fort McCoy save up to $40 \%$ in construction costs through extensions in the lifespan of the highway surface and elimination of the need to replace the subgrade of base roadways.

According to the climatological observing station near Fort McCoy in Sparta, WI, the area experiences an average 3 to 4.5 inches of rainfall each month from April to September with temperatures ranging from $40^{\circ} \mathrm{F}$ (4 $\left.{ }^{\circ} \mathrm{C}\right)$ in spring/early fall to $83^{\circ} \mathrm{F}\left(28^{\circ} \mathrm{C}\right)$ in the summer months. Through fall into winter, precipitation totals decline and snow begins to accumulate. In winter, temperatures drop as low as $3{ }^{\circ} \mathrm{F}\left(-16^{\circ} \mathrm{C}\right)$ with 10.4 inches of snow on average, along with an average of 140.5 freezing degree days. The summer months preceding the insulated pavements installation (April - September 2017) experienced above average rainfall, as high as 6.4 inches and 8.4 inches in June and July, respectively.

\subsection{Test setup}

In September 2017, a section of insulated pavement was installed in a welltrafficked road during a pre-existing repaving project at Fort McCoy. This scenario enabled Fort McCoy to execute planned repaving at no extra cost. 
Figure 1. (a) Aerial location of test area at Fort McCoy, WI, and (b) diagram of insulation, transition, and control section component composition and dimensions, and top-view of sensor placement.
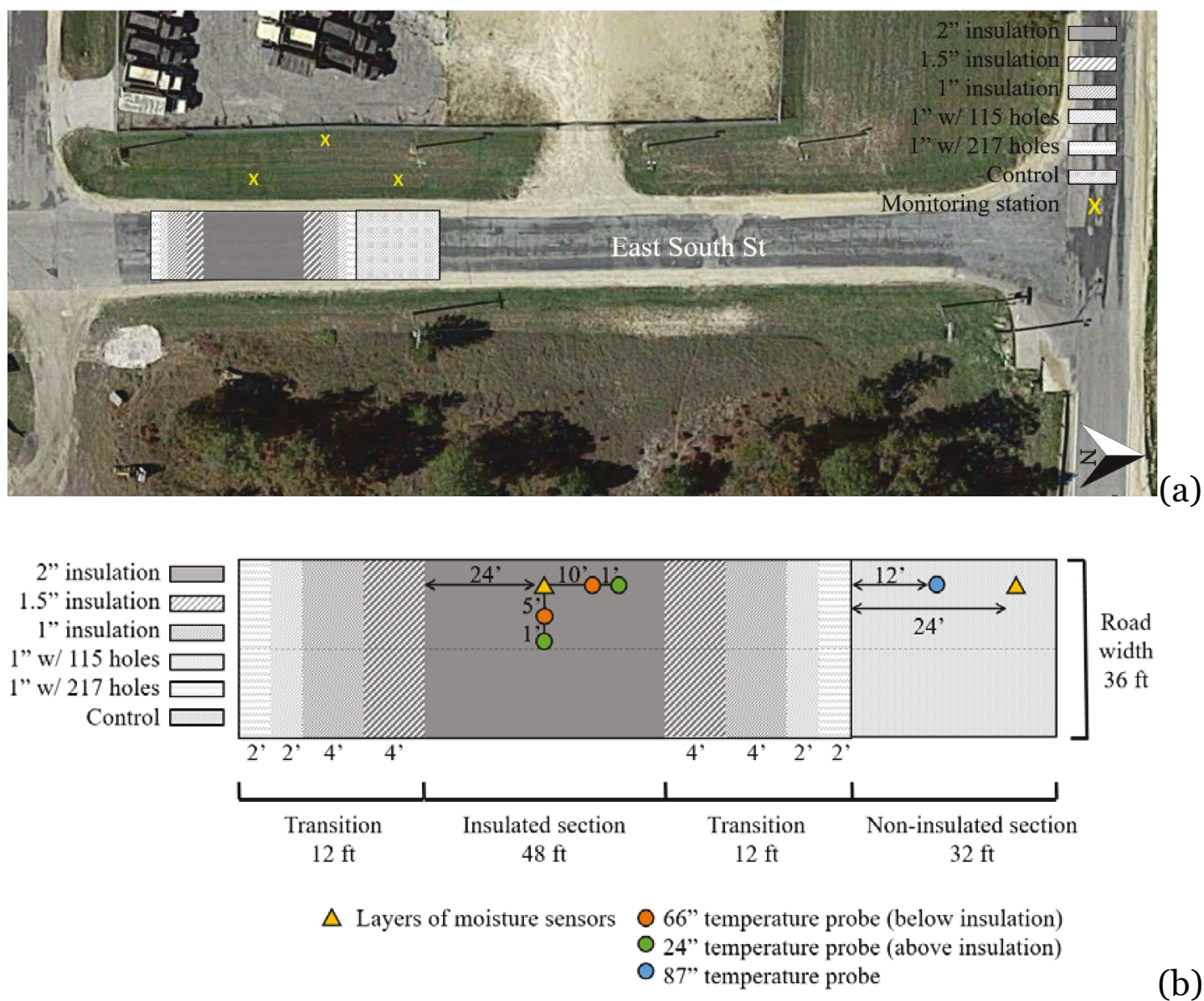

The test location consisted of a $104 \mathrm{ft}$ long, $36 \mathrm{ft}$ wide portion of East South Street (Figure 1a), which included transition regions on either side of the insulated pavement and a section of non-insulated pavement for a control section. Temperature sensors and moisture probes were installed above and below the thickest layer of insulation, as well as along the entire depth of the control section (Figure $1 \mathrm{~b}$ ). The sensors were connected to data loggers placed in monitoring stations located on the western roadside (denoted as a yellow $\mathrm{X}$ in Figure 1a).

The primary insulating layer consisted of $1,728 \mathrm{sq} f t$ of $4 \mathrm{ft} \times 8 \mathrm{ft} \times 2$ in. thick individual sheets of XPS material, also known as blue board, secured together with duct tape. Individual sheets of XPS were the most cost-effective method for fabrication and transportation. All sensors in this section were installed above and below the insulating layer in the center of the 
western lane of travel (Figure 1b). Transition regions of decreasing insulation thickness and surface area were placed on either side of the thickest insulating layer. This method was intended to reduce and/or prevent differential icing and heaving between adjacent insulated and non-insulated pavement sections. Both transition regions included $144 \mathrm{sq} \mathrm{ft} \mathrm{of} 4 \mathrm{ft} \times 8 \mathrm{ft} x$ 1.5 in. thick XPS, $144 \mathrm{sq} \mathrm{ft} \mathrm{of} 4 \mathrm{ft} \times 8 \mathrm{ft} \times 1$ in. XPS, $72 \mathrm{sq} \mathrm{ft} \mathrm{of} 2 \mathrm{ft} \times 8 \mathrm{ft} \times 1$ in. XPS with reduced surface area (115 1/2 in. diameter holes), and $72 \mathrm{sq} \mathrm{ft}$ of $2 \mathrm{ft} x 8 \mathrm{ft}$ x 1 in. XPS with further reduced surface area (217 1/2 in. diameter holes), totaling $432 \mathrm{sq} \mathrm{ft}$. The $\mathrm{R}$ value, or resistance to heat flow, of the 2 in., 1.5 in., and 1 in. boards were 10, 7.5, and 5, respectively. It is unknown by how much the $\mathrm{R}$ value was reduced by adding holes to the 1 in. thick insulation.

The non-insulated, or control section, was 1,152 sq ft in total area. Moisture sensors and a single temperature probe were installed at mirrored distances away from the transition section as the temperature and moisture sensors installed in the insulation section. In other words, the moisture sensors in both the insulated and non-insulated sections were placed the same distance from the edges of the transition region, and the same was true for the temperature probes. This placement provided similitude between the two sections such that temperature gradient effects from the transition region were equally felt, or not felt, on both sides.

The vertical profiles of the insulated and non-insulated pavement sections consisted of three primary layers: asphalt, base course, and subgrade (Figure 2). Each section had 4 in. of asphalt and 60 in. or more of subgrade material. In between, the insulated pavement had 18 in. of base course and up to 2 in. of XPS, while the non-insulated pavement had only 20 in. of base course material. When installing the temperature probes in the subgrade, standing water was visible approximately $38 \mathrm{in}$. below the subgrade surface in the insulated section, and 54 in. in the non-insulated section. The height of the water table was not known prior to beginning installation. The deepest temperature sensors were placed in the standing water and no moisture sensors were placed directly in the standing water. 
Figure 2. Vertical depth profile of the insulated (left) and non-insulated (right) pavement sections at the test site in Fort McCoy, WI. Sensor depths measured from bottom of asphalt layer; approximate depth of standing water is noted in each diagram.

Insulated

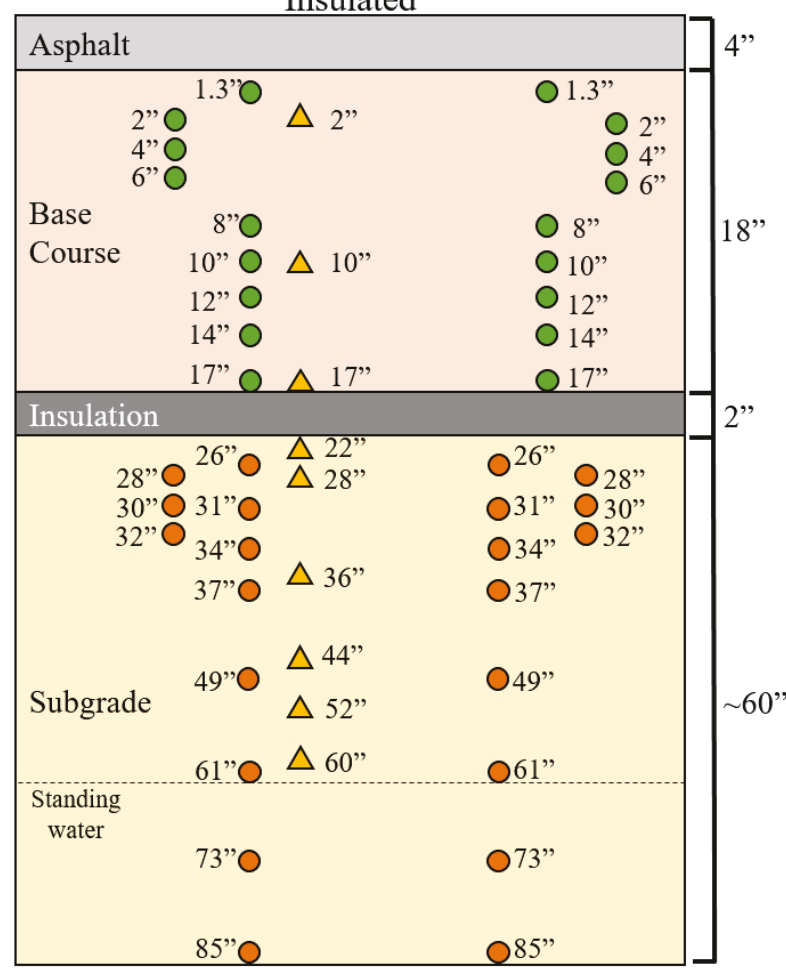

Non-Insulated

\begin{tabular}{|c|c|c|c|c|}
\hline \multicolumn{4}{|l|}{ Asphalt } & \multirow[t]{2}{*}{$4 "$} \\
\hline \multirow{5}{*}{$\begin{array}{l}\text { Base } \\
\text { Course }\end{array}$} & \multirow{5}{*}{$\begin{array}{r}9.5 " \bigcirc \\
11.5 " \bigcirc\end{array}$} & O 3" & $\triangle 2 "$ & \\
\hline & & & & $20 "$ \\
\hline & & O10" & $\triangle 12 "$ & \\
\hline & & O14" & & \\
\hline & & $\begin{array}{l}\text { O16"' } \\
\text { O 18" }\end{array}$ & & \\
\hline \multirow{7}{*}{ Subgrade } & & 0 & $\triangle 22$ & \multirow{9}{*}{$\sim 60$ "* } \\
\hline & & O $26 "$ & $\triangle 28^{\prime \prime}$ & \\
\hline & & O32" & $\triangle 36 "$ & \\
\hline & & O 44" & $\triangle 44 "$ & \\
\hline & & & $\triangle 52 "$ & \\
\hline & & O 56" & $\triangle 60 "$ & \\
\hline & & O 68" & $\triangle 68 "$ & \\
\hline \multirow[t]{2}{*}{$\begin{array}{c}\text { Standing } \\
\text { water }\end{array}$} & & & & \\
\hline & & O $80^{\prime \prime}$ & & \\
\hline
\end{tabular}

$\triangle$ Moisture sensors 66" temperature probes 24" temperature probes 87" temperature probe

The vertical thermal gradients of the insulated and non-insulated pavement sections were recorded using three different length temperature probes from Campbell Scientific (model CS230) - (2) 24 in. probes above the insulating layer, (2) 66 in. probes below the insulation layer, and (1) 87 in. probe in the control section. Each temperature probe contains a number of internal sensors along its length, as well as three external sensors with varying cord length placed near the top of the soil layer (Figure 2). The temperature probes above the insulating layer were laterally offset from the probes below the insulating layer by $1 \mathrm{ft}$ (Figure $1 \mathrm{~b}$ ). The offset was applied as result of having to puncture through the insulation in order to fit the $24 \mathrm{in}$. probe in the $18 \mathrm{in}$. depth of the base layer, avoiding the asphalt. Spray foam insulation was used to fill the gaps in the XPS created during this process. 
A number of Decagon $\mathrm{ECH}_{2} \mathrm{O}$ moisture sensors were positioned at varying depths in the insulated and non-insulated pavement sections to record the volumetric water content of the base course and subgrade layers throughout the winter freeze and spring thaw cycles. The vertical profile of the soil moisture provided a baseline of the natural water content in the test area, as well as insight into how the soil moisture behaved with changing temperatures. This information was further used to determine whether the insulating layer was effective in preventing moisture from reaching the frostsusceptible subgrade and if freezing occurred.

All sensor cables were directed to the western roadside and connected to Campbell Scientific data loggers. One station was set up for the insulated and one for the non-insulated pavement section. The monitoring stations themselves consisted of a water-tight box and an $18 \mathrm{in} . \mathrm{x} 21 \mathrm{in}$. solar panel mounted on a $4 \mathrm{ft}$ x $4 \mathrm{ft} \times 12 \mathrm{ft}$ post. Electronics and batteries were housed in the box. The two roadside stations were connected via Ethernet to a third station placed more west of the roadside, housing the satellite reporting equipment. Two solar panels and a large battery were installed in this station.

Additionally, several FWD tests were performed on the road over the course of the winter season and spring thaw to gauge how the road's structural properties changed during the spring thaw cycle. Figure 3 shows the approximate locations of each FWD drop site. Four loading forces of increasing weight were applied at each test site, ranging from $5500 \mathrm{lbs}$ to 15,000 lbs. Four drops per loading force were conducted, totaling 16 drops at each site. Back calculations of the elastic moduli for each pavement layer were completed for a loading force around 9,00o lbs using the MODULUS 7 software. The program was configured as a three-layer system with a semi-infinite subgrade layer defined as silty sand and pavement surface temperature defined by the closest installed temperature probe.

Over the course of the experiment the test section was used normally by the traffic at Fort McCoy, meaning less traffic in the winter months, increasing traffic through spring and summer. 
Figure 3. Approximate locations of the falling weight deflectometer (FWD) tests performed on East South Street at Fort McCoy.

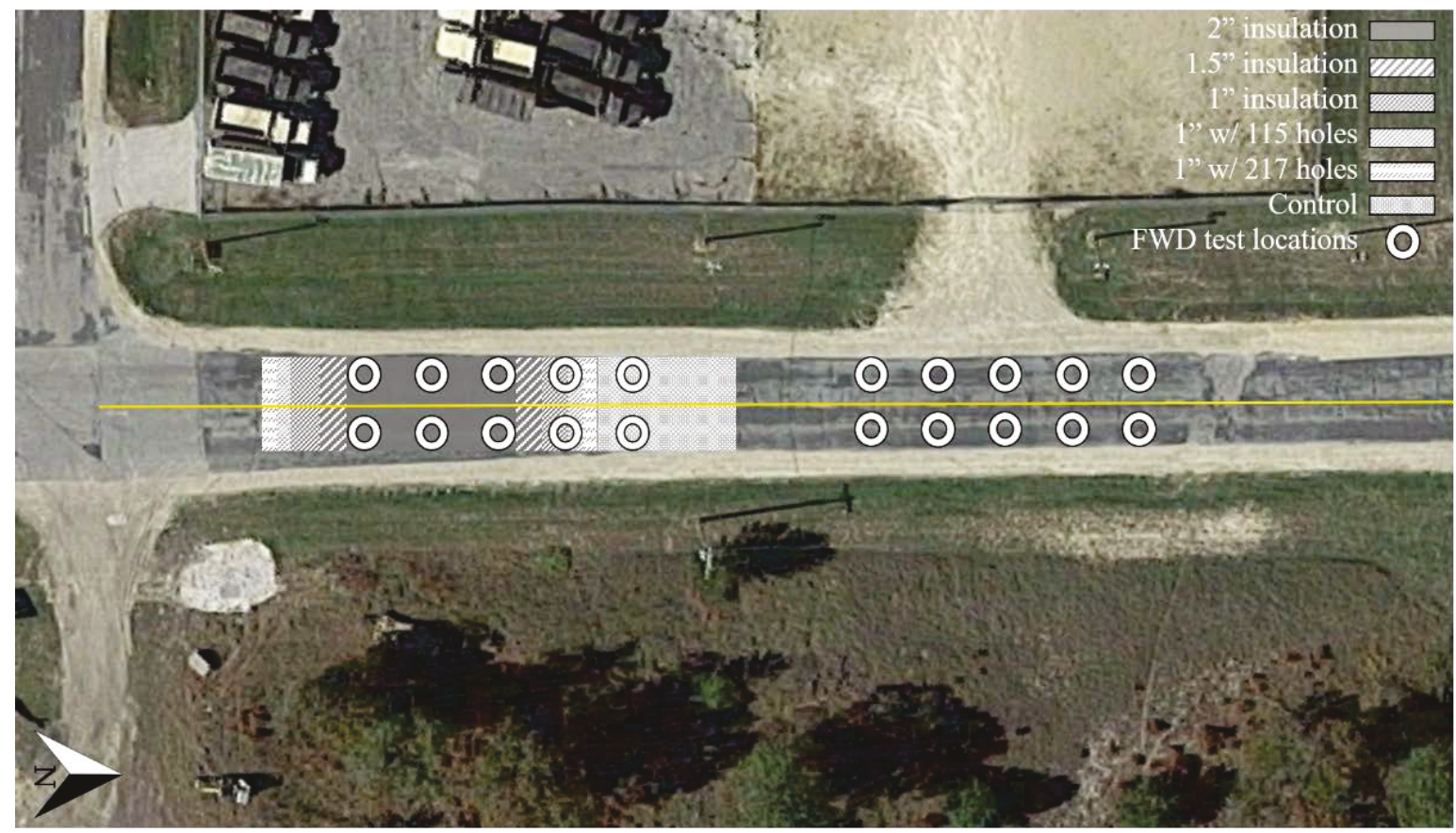

\subsection{Results}

The monthly temperature and moisture content gradients were compared between the insulated and non-insulated pavements. The change in elastic moduli was also compared between the two pavement sections over the 2017 - 2018 winter freeze and spring thaw cycle.

Below the insulating layer, the soil temperature remained above $5{ }^{\circ} \mathrm{C}$ through the winter freeze and spring thaw cycle (Figure 4a). In the non-insulated pavement section, the subgrade temperature dipped below $0{ }^{\circ} \mathrm{C}$ and up to $4.5^{\circ} \mathrm{C}$ during February and March. While the frost susceptible soil remained above freezing, the base course above the insulating layer was $2-3{ }^{\circ} \mathrm{C}$ colder during the winter months than the conventional pavement at the same depths. This phenomenon is what causes differential icing, where a section of the insulated pavement surface can accumulate ice while the conventional pavement will not. Unfortunately, differential icing was not monitored at the test location during this experiment. 
Figure 4. (a) Temperature gradient in ${ }^{\circ} \mathrm{C}$ and (b) percent water content (i.e., moisture) of insulated (left) and non-insulated (right) pavement sections for October 2017 through June 2018; depth is measured from the bottom of the asphalt layer.
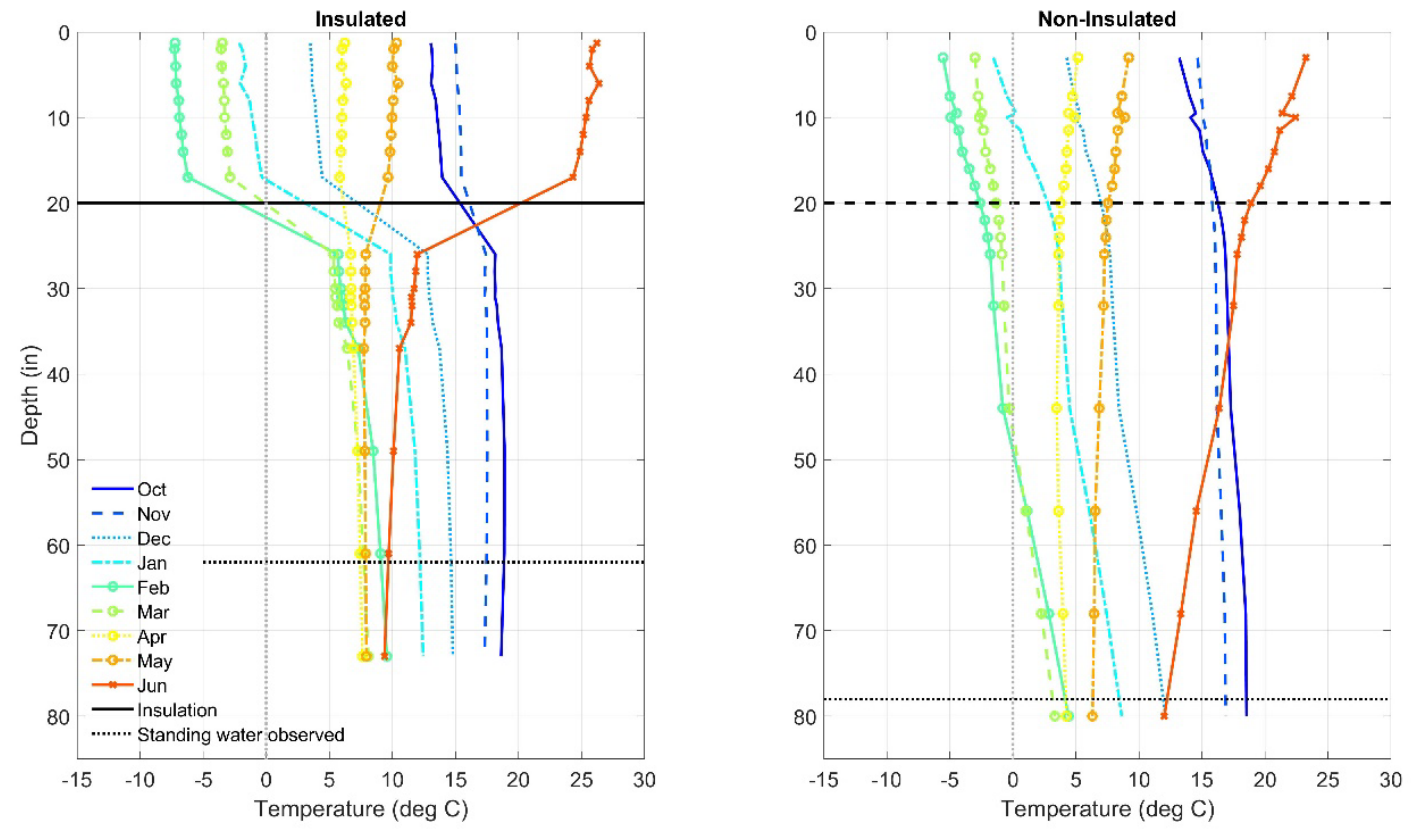

(a)
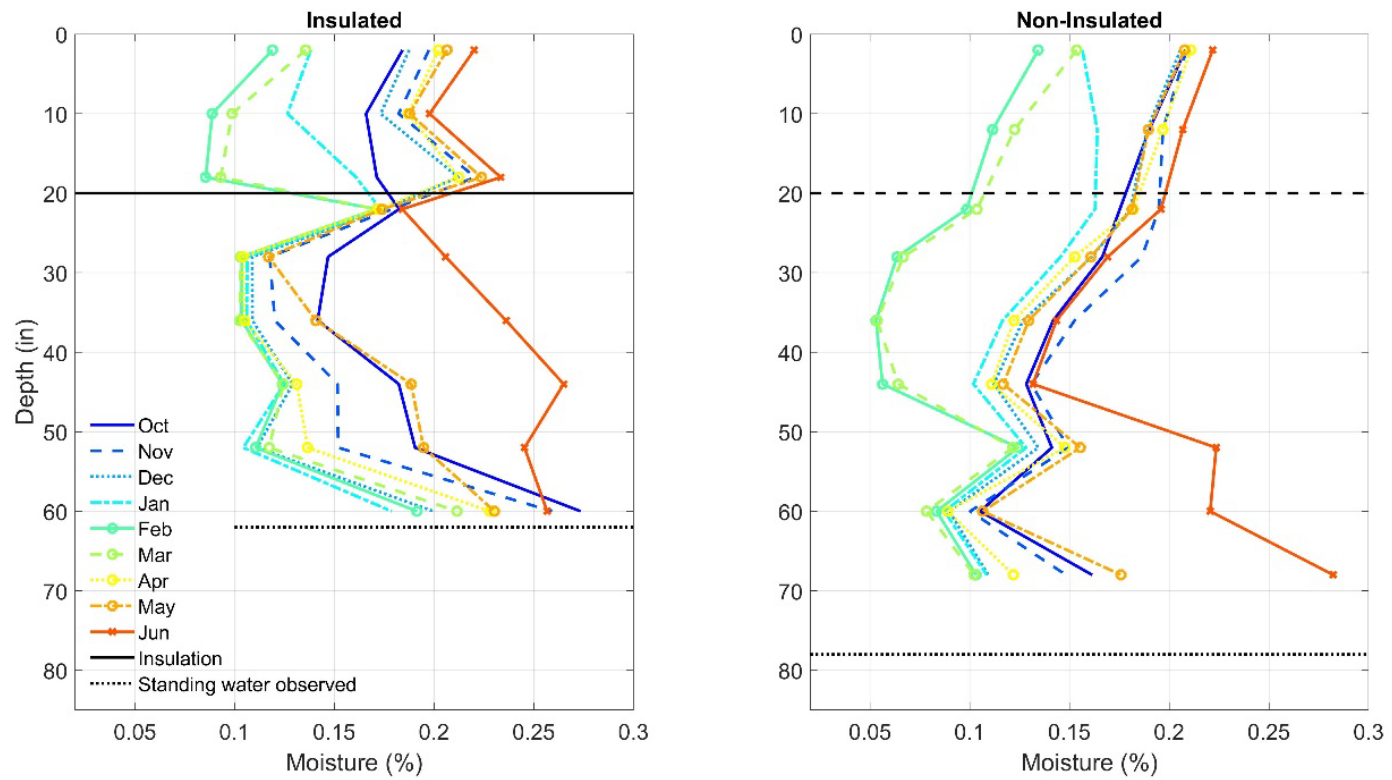

(b)

The temperature gradient suggest that the insulating layer had the intended effect of preventing the frost susceptible soil from freezing. The amount of moisture or water content in the soil provides an indication of frost penetration (Figure 4b). In theory, the insulating layer was intended 
to prevent moisture and freezing temperature from penetrating the subgrade. A lack of moisture is an indicator for frozen soil. Compared to the conventional pavement, the insulated pavement retained about $5-10 \%$ more moisture during the winter months between 22 and 48 in. The lack of moisture in the conventional pavement at the same depth suggests frozen soil. In general, the insulated pavement shows a higher water content than in the conventional pavement throughout the entire season. Most notably, the moisture just beneath the insulating layer (22 inches in from bottom of pavement) was near constant each month, suggesting that the initial moisture content of the soil during installation in October 2017 was preserved by the insulating layer at this depth.

While the water content is higher in the insulated pavement, the insulating layer prevented subgrade soil temperatures from freezing. From this, it can be estimated that frost penetration was minimal.

The increased water content in the insulated pavement could be caused by the height of the pre-existing water table in this area compared with the control, or non-insulated section. The presence of increased moisture effects the elastic moduli of the subgrade, making the soil softer and weaker. In theory, the elastic moduli of the subgrade should increase during the winter months due to ice formation in the material, and fluctuate slightly during the spring thaw period. With the insulating layer, the fluctuations in the elastic moduli should be minimal since the soil temperature is intended to remain relatively consistent. The presence of standing water in the subgrade, however, may influence the temperature and moisture content of the soil, which can lead to inconsistencies in the back calculated moduli values.

Results from the FWD tests indicate there was no significant difference in elastic modulus of the subgrade between the insulated and non-insulated pavement sections (Figure 5). The moduli increased in the winter and fluctuated slightly during the spring thaw. The subgrade was hardest during the harshest winter months, returning to its autumnal values over the course of the spring thaw. Most notable is the difference between the western and eastern lanes of the insulated pavement. The moduli in the winter is $4 \mathrm{ksi}$ stronger in the eastern lane than in the western lane; and during spring, the moduli is consistently 1 ksi lower in the eastern lane. The western lane of East South Street contained the temperature and moisture instrumentation. The installment of these sensors could have impacted the 
strength of the subgrade during the test period (e.g., water penetration along the edges of the temperature probes or cables).

Figure 5. Back calculated elastic moduli in ksi of the subgrade layer (frost susceptible soil) in the insulated and non-insulated pavement section in the western and eastern lanes of East South Street.
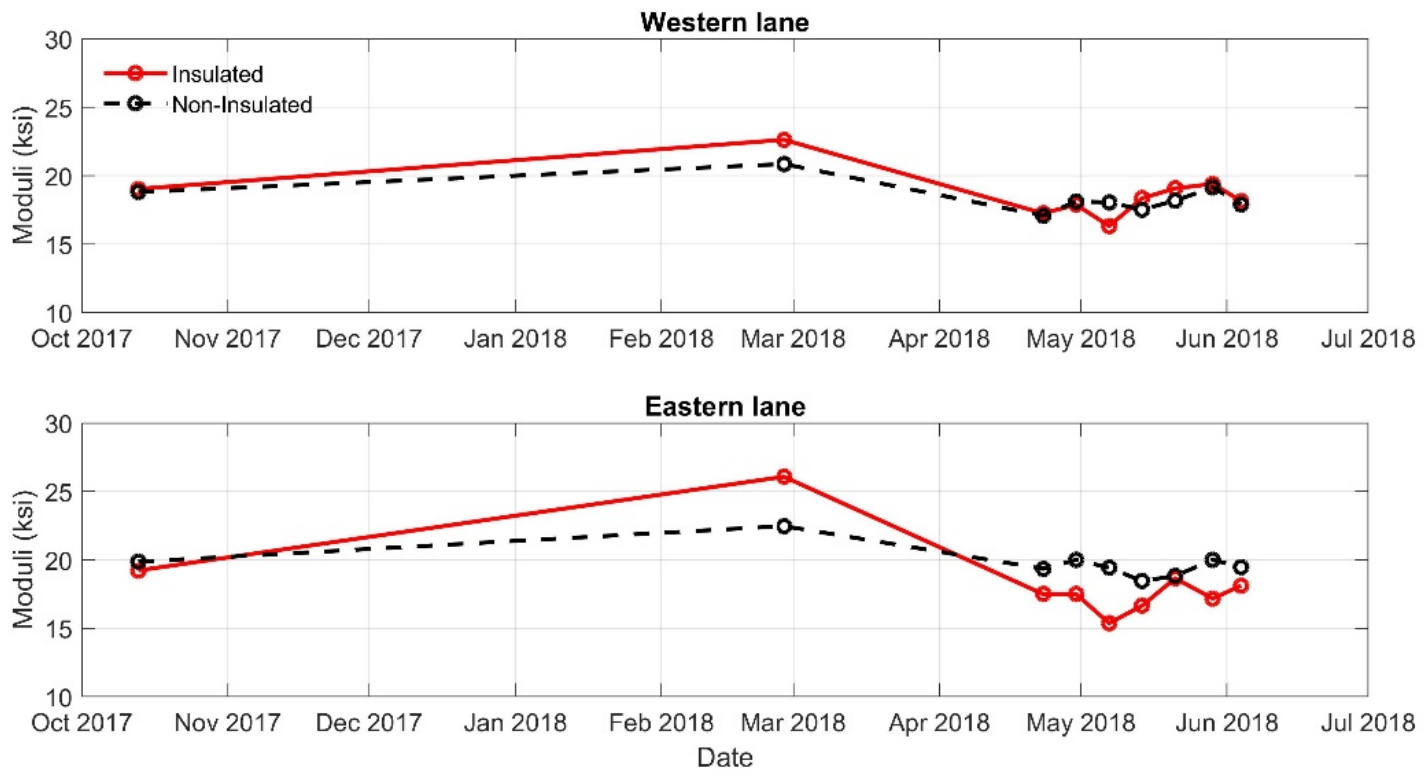

Kestler (1995) noticed the effect of high groundwater on pavement strength at the Jackman, ME, airport. This effect is further detailed in Zhang (2004). Essentially, the presence of a high water table beneath insulated and non-insulated pavements causes the subgrade to remain weak during what would otherwise be a recovery period. In future studies/applications, ground penetrating radar (GPR) should be used to determine the depth of the water table prior to installing an insulating layer. This practice may change the construction/installation plan of the pavement. 


\section{Summary}

General Army construction standards do not incorporate the use of insulated pavements at Army installations in cold regions. Frost heaving is a constant burden on any facility in cold regions, causing accelerated deterioration of roadways and annual maintenance, which ultimately leads to costly repair and reconstruction efforts. Insulated pavements have been demonstrated as cost effective in several civilian locations, and have shown exceptional resistance to compression and water absorption. The objective of this study was to evaluate the effectiveness of insulated pavement in eliminating the impact of frost action on roadways for the purpose of reducing annual roadway maintenance and redefining the standards governing its application.

An insulating layer of extruded polystyrene (XPS) was installed in a section of road at Fort McCoy, WI. The layer covered a total 2,160 sq ft of road using varying thicknesses of XPS ( $1-2$ in.). Temperature and moisture sensors were installed to monitor the effectiveness of the insulating layer. These data were compared to similar measurements taken in the $1,152 \mathrm{sq} \mathrm{ft}$ non-insulated pavement section on the same road. Data was recorded from October 2017 through June 2018. FWD tests were conducted over the same time period to monitor pavement strength.

The monthly temperature and moisture content gradients were compared between the insulated and non-insulated pavements. The change in elastic moduli was also compared between the two pavement sections over the $2017-2018$ winter freeze and spring thaw cycle. The insulating layer was shown to be effective in preventing frost from penetrating the subgrade. Temperatures remained well above freezing $\left(8^{\circ} \mathrm{C}\right.$ or $\left.46^{\circ} \mathrm{F}\right)$ in the subgrade throughout the winter months. Further, the vertical moisture gradient demonstrated minimal signs of frost penetration. The non-insulated pavement experienced a decrease in water content (i.e., moisture) in the subgrade layer during January and February, suggesting the soil froze at these depths. FWD tests indicated an unappreciable difference between the insulated and non-insulated pavement. The presence of a high water table beneath the test pavement sections are believed to have affected the strength of the subgrade, especially through the post spring thaw recovery period. 
Differential icing and heaving effects due to the presence of the insulating layer were not explicitly monitored. The vertical temperature gradient above the XPS indicated increased freezing in the base course during the winter months compared to the non-insulated pavement $\left(2-3{ }^{\circ} \mathrm{C}\right.$ colder in top 18 in.). These data suggest that the potential for surface icing may have increased in winter and different icing may have occurred. However, the presence of the transition section between the insulated and non-insulated pavement sections was intended to reduce and/or eliminate the effect of differential icing and heaving. 


\section{References}

Côté, Jean, and Jean-Marie Konrad. 2006. Granular protection design to minimize differential icing on insulated pavements. Canadian Geotechnical Journal 43(3): 260-272.

Departments of the Army, Navy, and Air Force. Feb 1997. Flexible Pavement Design for Airfields. TM 5-825-2/NAVFAC DM23.1 /AFJMAN 32-1014. Washington, DC.

Esch, David C. 1995. "Long-Term Evaluations of Insulated Roads and Airfields in Alaska, Monograph: Environmental moisture effects on transportation facilities and nonearth materials' thermal effects on pavements." Transportation Research Record 1481.

Kestler, Maureen A., and Richard L. Berg. 1995. "Case Study of Insulated Pavement in Jackman, Maine.” Transportation Research Record 1481, p 47-55. Washington, DC: Transportation Research Board.

Scullion, T., J. Uzan, and M. Paredes. 1990. MODULUS: A Microcomputer-Based Backculation System. Transportation Research Record 1260, pp. 180-191.

Tart, Rupert G. 2007. "Pavement Distress and Roadway Damage Caused by Subsurface Moisture and Freezing Temperatures: Case Histories from Alaska." Transportation Research Record 1709, Paper No. 00-0681, pp 91-97. Washington, DC: Transportation Research Board.

Vinson, T.S., J.W. Rooney, and W.H. Haas, eds. 1996. Roads and airfields in cold regions: A state of the practice report. ASCE Publications.

Zhang, Chaohan. 2004. The Effect of High Groundwater Level on Pavement Subgrade Performance. Ph.D. Dissertation. Tallahassee, FL: Florida State University. 


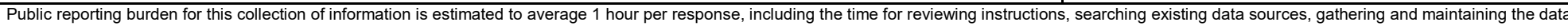

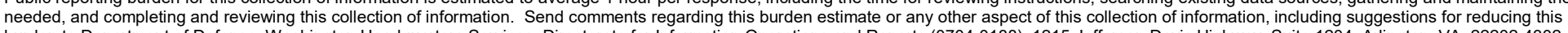

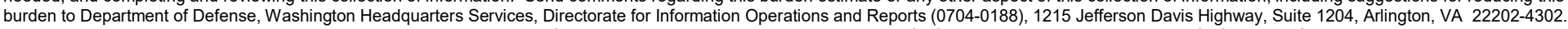

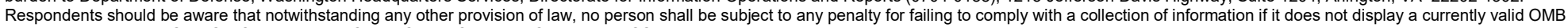
control number. PLEASE DO NOT RETURN YOUR FORM TO THE ABOVE ADDRESS.
1. REPORT DATE (DD-MM-YYYY)
December 2018

\section{TITLE AND SUBTITLE}
2. REPORT TYPE
Final
3. DATES COVERED (From - To)
5a. CONTRACT NUMBER

Evaluation of Insulated Pavements to Prevent Frost Damage

5b. GRANT NUMBER

5c. PROGRAM ELEMENT NUMBER

6. AUTHOR(S)

5d. PROJECT NUMBER

463294

Marissa J. Torres, Alexander R. Stott, and Marina I. Reilly-Collette

5e. TASK NUMBER

5f. WORK UNIT NUMBER

7. PERFORMING ORGANIZATION NAME(S) AND ADDRESS(ES)

U.S. Army Engineer Research and Development Center (ERDC)

Cold Regions Research Engineering Laboratory (CRREL)

NUMBER

ERDC/CRREL TR-18-21

72 Lyme Road

Hanover, NH 03755

\section{SPONSORING / MONITORING AGENCY NAME(S) AND ADDRESS(ES)}

Office of the Assistant Chief of Staff for Installaton Management (OACSIM)

600 Pentgon

Washington DC 20310

10. SPONSOR/MONITOR'S ACRONYM(S)

OACSIM

11. SPONSOR/MONITOR'S REPORT NUMBER(S)

12. DISTRIBUTION / AVAILABILITY STATEMENT

Approved for public release. Distribution is unlimited.

\section{SUPPLEMENTARY NOTES}

\section{ABSTRACT}

Frost heaving is a constant burden on any facility in cold regions, causing accelerated deterioration of roadways and annual maintenance, leading to costly re-pairs. Insulated pavements have been demonstrated as cost effective in several civilian locations, and have shown exceptional resistance to compression and water absorption. The objective of this study was to evaluate the effectiveness of insulated pavement in eliminating the impact of frost action on roadways for the purpose of reducing annual roadway maintenance and redefining the standards governing its application.

An insulating layer of extruded polystyrene (XPS) was installed in a section of road at Fort McCoy, WI. The monthly temperature and moisture content gradients were compared between the insulated and non-insulated pavements. The change in elastic moduli was also compared between the two pavement sections over the 2017-2018 winter freeze and spring thaw cycle. The insulating layer was shown to be effective in preventing frost from penetrating the subgrade. Temperatures remained above freezing in the subgrade throughout the winter. The vertical moisture gradient demonstrated minimal signs of frost penetration. The presence of a high water table beneath the test pavement sections are believed to have affected the strength of the subgrade, especially through the post spring thaw recovery period.

\section{SUBJECT TERMS}

Pavements--Frost damage, Pavements--Cold regions, Frost damage-Testing, Roads--Frost damage, Polystyrene, Roads--Snow and ice control, Fort McCoy (Wis.)

\begin{tabular}{|c|c|c|c|c|c|}
\hline \multicolumn{3}{|c|}{ 16. SECURITY CLASSIFICATION OF: } & \multirow{2}{*}{$\begin{array}{l}\text { 17. LIMITATION } \\
\text { OF ABSTRACT } \\
\text { UU }\end{array}$} & \multirow{2}{*}{$\begin{array}{l}\text { 18. NUMBER } \\
\text { OF PAGES } \\
24\end{array}$} & 19a. NAME OF RESPONSIBLE PERSON \\
\hline $\begin{array}{l}\text { a. REPORT } \\
\text { Unclassified }\end{array}$ & $\begin{array}{l}\text { b. ABSTRACT } \\
\text { Unclassified }\end{array}$ & $\begin{array}{l}\text { c. THIS PAGE } \\
\text { Unclassified }\end{array}$ & & & $\begin{array}{l}\text { 19b. TELEPHONE NUMBER } \\
\text { (include area code) }\end{array}$ \\
\hline
\end{tabular}

